\title{
Implementation of X-Ray Microscopy and Micro-XANES Analysis for Investigations of the Cellular Uptake and Cellular Metabolism of Transition Metals
}

C. T. Dillon, B. J. Kennedy, P. A. Lay, B. Lai,* Z. Cai,* A. P. J. Stampfl, *广 P. Ilinski, * D. G. Legnini, * J. Maser, ${ }^{*}$ W. Rodrigues, ${ }^{*}$ G. Shea-McCarthy ${ }^{\star}$ and M. Cholewa. ${ }^{\S}$

Centre for Heavy Metals Research, School of Chemistry, University of Sydney, NSW, 2006.

*Experimental Facilities Division, Argonne National Laboratory, Argonne, IL, 60439, USA.

$\dagger$ Physics Division, Australian Nuclear Science and Technology Organisation, Lucas Heights, NSW, 2234, Australia.

Brookhaven National Laboratory, Upton, New York.

${ }^{\S}$ Gesellschaft fuer Schwerionenforschung mbH, 64291 Darmstadt, Germany

Corresponding author : $\quad$ Barry Lai

Experimental Facilities Division

Argonne National Laboratory

Argonne, IL 60439

USA

Ph. 630-252-6405

Fax. 630-252-9303

blai@aps.anl.gov 
C. T. Dillon, B. J. Kennedy, P. A. Lay, B. Lai, Z. Cai; A. P. J. Stampfl; P. Ilinski, D. G. Legnini, J. Maser, W. Rodrigues, G. Shea-McCarthy and M. Cholewa.

\author{
This space should be left blank, except for the names of the authors. (The publisher will re-type \\ the main title, author names and addresses. Please give this information on a separate page.)
}

\begin{abstract}
Micro-SRIXE (synchrotron-radiation-induced X-ray emission) and micro-XAS (X-ray absorption spectroscopy) were used to probe the uptake of exogenous metals by cells. The high flux and the sub-micron resolution of the hard X-ray microprobe, offer the experimenter the ability to obtain highly sensitive spatial and structural information of cellular elements. In this work the uptake of carcinogenic $\mathrm{Cr}(\mathrm{VI})$ was compared with that of a relatively non-toxic $\mathrm{Cr}$ (III) complex by micro-SRIXE mapping of whole cells. High intracellular $\mathrm{Cr}$ concentrations were observed in $\mathrm{Cr}(\mathrm{VI})$-treated cells, while no significant $\mathrm{Cr}$ uptake was observed for $\mathrm{Cr}$ (III)treated cells, as is consistent with uptake studies performed by other techniques. Micro-XANES analysis of $\mathrm{Cr}(\mathrm{V})$ and $\mathrm{Cr}(\mathrm{VI})$-treated cells showed that the predominant oxidation product following cellular metabolism was $\mathrm{Cr}$ (III). As shown by X-ray microscopic analysis of thin-sectioned cells, however, the reduction of $\mathrm{Cr}$ (VI) to $\mathrm{Cr}$ (III) did not occur at a fast enough rate to exclude $\mathrm{Cr}$ entry into the cell nucleus.
\end{abstract}

\title{
1. INTRODUCTION
}

It is well documented that $\mathrm{Cr}(\mathrm{VI})$ causes cancer following occupational exposure, and it is becoming increasingly evident that adverse effects from $\mathrm{Cr}(\mathrm{VI})$ may also extend to environmental exposure [1-3]. Therefore, understanding the mechanisms of $\mathrm{Cr}$ carcinogenesis is essential in order to minimise/negate these adverse effects.

X-Ray microscopy (micro-SRIXE) is a powerful technique for spatial analysis of elements at submicron to micron resolution. Consequently, the technique has been applied to the study of the cellular uptake of the carcinogen, $\mathrm{Cr}(\mathrm{VI})$, the $\mathrm{Cr}(\mathrm{III})$ mutagen, $\left[\mathrm{Cr}(\mathrm{phen})_{2}\left(\mathrm{OH}_{2}\right)_{2}\right]^{3+}$, and its $\mathrm{Cr}(\mathrm{V})$ analogue, $\left[\mathrm{CrO}(\text { phen })_{2}\right]^{+}$. Sub-micron mapping of thin-sectioned cells to determine intracellular targets is also described. Finally, the capabilities of micro-XANES are alluded to in the study of Cr-treated cells wherein information concerning the intracellular metabolism of $\mathrm{Cr}$ is deduced.

\section{METHOD}

All solutions and cell media were prepared in milli-Q water. $\mathrm{Na}_{2} \mathrm{Cr}_{2} \mathrm{O}_{7}$ (Merck, AR grade) was used as received. cis- $\left[\mathrm{Cr}(\text { phen })_{2}\left(\mathrm{OH}_{2}\right)_{2}\right]\left(\mathrm{NO}_{3}\right)_{3} \cdot 2.5 \mathrm{H}_{2} \mathrm{O}$ was prepared, purified and oxidized to produce the $\mathrm{Cr}(\mathrm{V})$ analogue as reported in the literature [4-6].

Whole V79 Chinese hamster lung cells were prepared for X-ray microprobe analysis according to methods detailed by Dillon, et al. [6] in which the cells $\left(\sim 10^{6}\right)$ were treated with the following $\mathrm{Cr}$ complexes: $\mathrm{Na}_{2} \mathrm{Cr}_{2} \mathrm{O}_{7}, 0.1 \mathrm{mM}$; cis- $\left[\mathrm{Cr}^{\mathrm{III}}(\text { phen })_{2}\left(\mathrm{OH}_{2}\right)_{2}\right]^{3+}$ or $c i s-\left[\mathrm{Cr}^{\mathrm{V}}(\mathrm{O})_{2}(\text { phen })_{2}\right]^{+}, 0.4 \mathrm{mM}$.

Hard X-ray microprobe experiments were performed on SRI-CAT beamline 2ID-D at the Advanced Photon Source, Argonne National Laboratory [6]. All measurements were conducted using a monochromatic $10-\mathrm{keV} \mathrm{X}$-ray incident beam, and under a He atmosphere in order to eliminate the Ar Kshell fluorescence signal (from air). A number of fluorescence maps ( $\mathrm{P}, \mathrm{Cl}, \mathrm{K}, \mathrm{Ca}, \mathrm{Cr}, \mathrm{Fe}, \mathrm{Cu}$, and $\mathrm{Zn}$ ) corresponding to the integrated $\mathrm{K}_{\alpha}$ fluorescence signal were simultaneously collected for each twodimensional scan. Whole cells (4-6 per sample) were analyzed using a beam that was focused to approximately $1 \times 0.3 \mu^{2}$ using a phase-zone-plate-based scanning hard X-ray microprobe. Scans were acquired in 1- $\mu \mathrm{m}$ steps, and the emitted X-rays were detected for $3 \mathrm{~s}$ per point using a Canberra UltraLEGe germanium X-ray detector. The detector had an energy resolution of $\sim 200 \mathrm{eV}$ over the range of elements examined. Microprobe measurements of thin-sectioned cells were performed using a $0.3-\mu \mathrm{m}$ 
diameter X-ray beam. Areas of $(12 \times 12) \mu \mathrm{m}^{2}$ were scanned in steps of $0.3 \mu \mathrm{m}$ at $6 \mathrm{~s}$ per point. The analysis for each set of elemental maps was performed as described [6]. Statistical analyses were performed on the results of whole cell elemental distributions using ANOVA, Tukey-Kramer Multiple Comparison Test [7,8].

Micro-XANES analyses of cellular $\mathrm{Cr}$ were performed at Brookhaven National Laboratory, beamline X26A using a 200- $\mu \mathrm{m}$ X-ray beam [9].

\section{RESULTS AND DISCUSSION}

Micro-SRIXE images of whole cells exposed to $\mathrm{Cr}(\mathrm{III}), \mathrm{Cr}(\mathrm{V})$ or $\mathrm{Cr}(\mathrm{VI})$ (Figure 1) showed increased definition in the $\mathrm{Cr}$ maps for the $\mathrm{Cr}(\mathrm{V})$ - and $\mathrm{Cr}(\mathrm{VI})$-treated cells. The low intensity map of Cr following cell treatment with $\mathrm{Cr}$ (III) is consistent with related studies that show that $\mathrm{Cr}$ (III) does not enter cells to any appreciable extent, while $\mathrm{Cr}(\mathrm{VI})$, which is isostructural with sulfate and phosphate, is readily taken up [2]. Inspection of the $\mathrm{Cr}$ maps indicates that $\mathrm{Cr}$ is distributed throughout the cell and is not solely located in areas of high $\mathrm{P}, \mathrm{K}$, or $\mathrm{Zn}$ concentrations.

$\mathbf{P}$

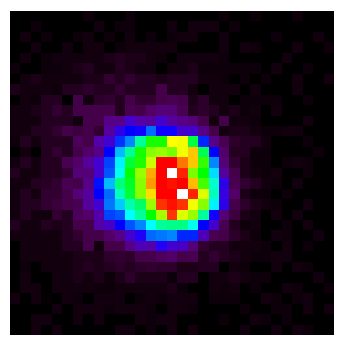

A
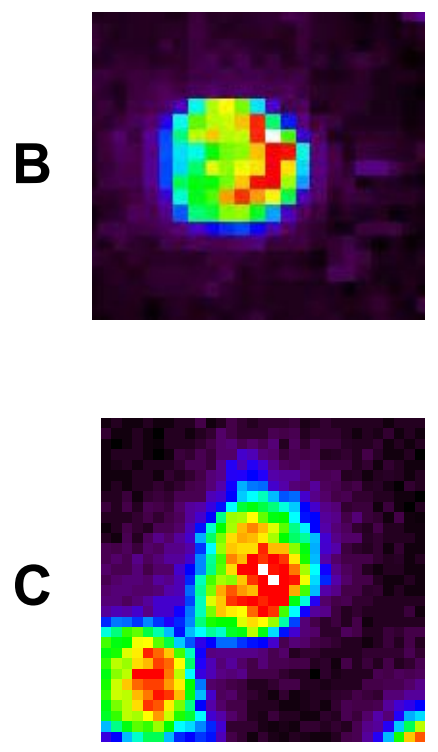

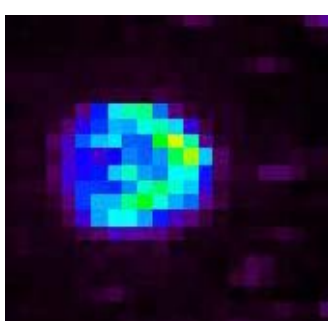

$\mathbf{K}$
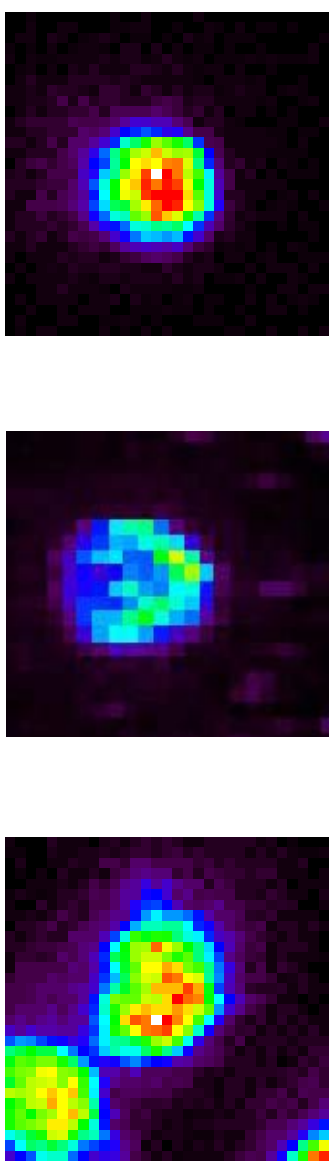

Zn
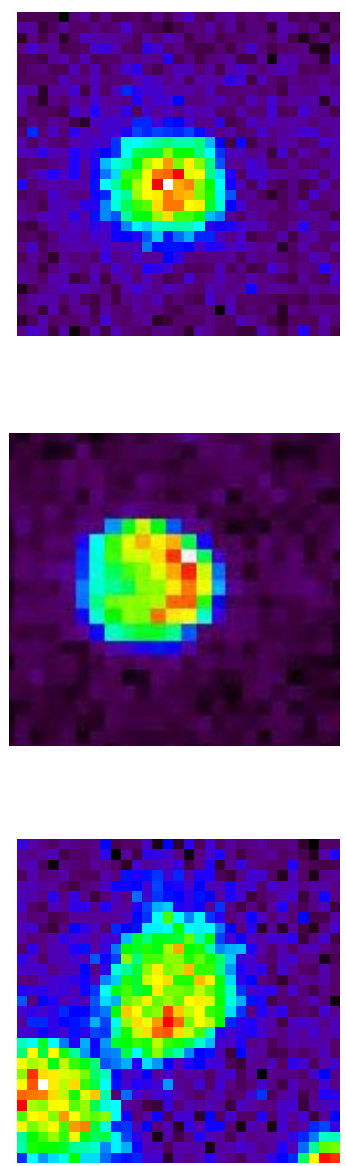

$\mathrm{Cr}$
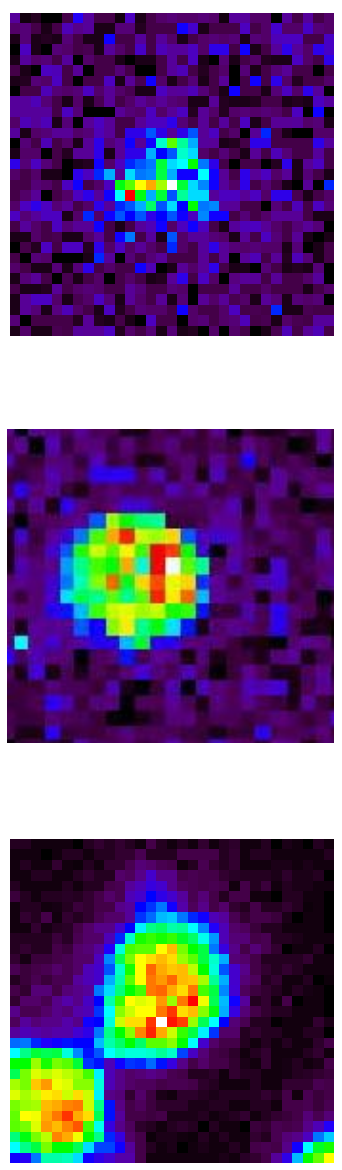

\section{Min}

$\operatorname{Max}$

Figure 1. Micro-SRIXE maps of whole V79 Chinese hamster lung cells treated with: $\mathrm{A},\left[\mathrm{Cr}^{\mathrm{III}}\left(\mathrm{phen}_{2}\right)_{2}\left(\mathrm{OH}_{2}\right)_{2}\right]^{3+}, 0.4 \mathrm{mM} ; \mathrm{B}$, $\left[\mathrm{Cr}^{\mathrm{v}}(\mathrm{O})_{2}(\text { phen })_{2}\right]^{+}, 0.4 \mathrm{mM}$; and $\mathrm{C},\left[\mathrm{CrO}_{4}\right]^{2-}, 0.1 \mathrm{mM}$. Adapted with permission from [6], Copyright [2002], Society of Biological Inorganic Chemistry.

Importantly, there was no significant increase in intracellular $\mathrm{Cr}$ following treatment with $\mathrm{Cr}(\mathrm{III})$ (Figure 2); there were, however, detectable increases in intracellular $\mathrm{Cr}$ following treatment with the $\mathrm{Cr}(\mathrm{V})$ analogue, $\left[\mathrm{Cr}^{\mathrm{V}}(\mathrm{O})_{2}(\text { phen })_{2}\right]^{+}$, and $\mathrm{Cr}(\mathrm{VI})$. This is consistent with previous findings that $\mathrm{Cr}(\mathrm{V})$ and $\mathrm{Cr}(\mathrm{VI})$ increase the incidence of micronuclei formation, an indicator of genotoxic damage (Figure 3 ). Furthermore, the intracellular oxidation of $\mathrm{Cr}(\mathrm{III})$ to $\mathrm{Cr}(\mathrm{V})$ may account for the milder but significant increase in micronuclei following treatment with $\mathrm{Cr}(\mathrm{III})$ phen. 


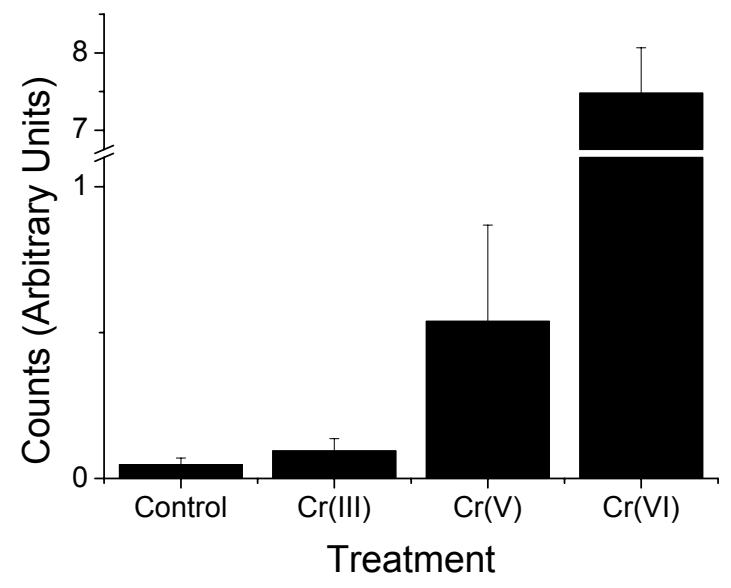

Figure 2. Cellular uptake of $\mathrm{Cr}$ following treatment of cells with: $\quad\left[\mathrm{Cr}^{\mathrm{III}}(\text { phen })_{2}\left(\mathrm{OH}_{2}\right)_{2}\right]^{3+}, \quad 0.4 \mathrm{mM}$, $\left[\mathrm{Cr}^{\mathrm{V}}(\mathrm{O})_{2}(\text { phen })_{2}\right]^{+}, 0.4 \mathrm{mM}$ and $\left[\mathrm{CrO}_{4}\right]^{2-}, 0.1 \mathrm{mM}$. Sample size, $\mathbf{n}=4-6$, and columns represent means \pm SD. Reprinted with permission from [6], Copyright [2002], Society of Biological Inorganic Chemistry.

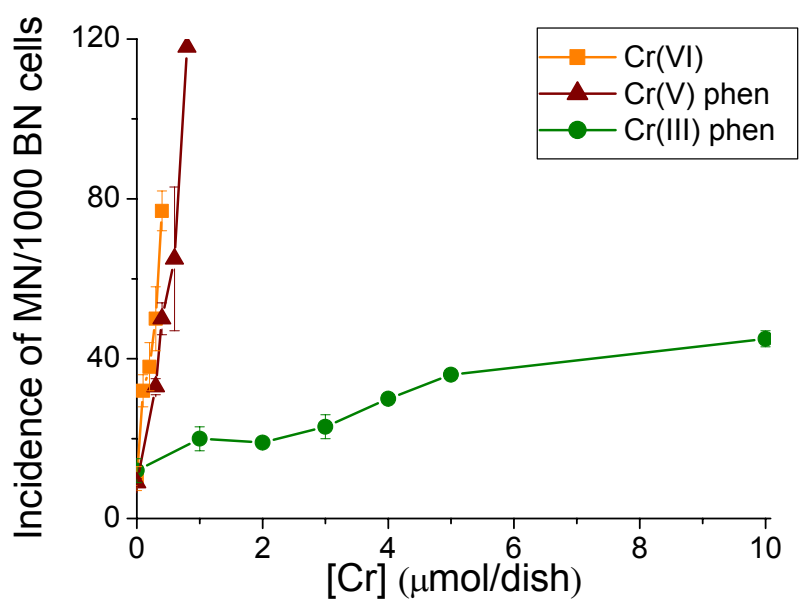

Figure 3. Incidence of micronuclei in binucleated V79 Chinese hamster lung cells following treatment with: $\left[\mathrm{Cr}^{\mathrm{III}}(\text { phen })_{2}\left(\mathrm{OH}_{2}\right)_{2}\right]^{3+}, \quad\left[\mathrm{Cr}^{\mathrm{V}}(\mathrm{O})_{2}(\text { phen })_{2}\right]^{+}$and $\left[\mathrm{CrO}_{4}\right]^{2-}$. Sample size, $\mathbf{n}=2$, and data points represent means and error bars represent the SD.

Micro-XAS analyses (Figure 4), performed using a 200- $\mu \mathrm{m}$ diameter beam, were used to establish the oxidation state of the intracellular $\mathrm{Cr}$ following exposure to $\mathrm{Cr}(\mathrm{V})$ and $\mathrm{Cr}(\mathrm{VI})$ mutagens and carcinogens [9]. Most of the $\mathrm{Cr}$ was reduced to the impermeable $\mathrm{Cr}$ (III) form.

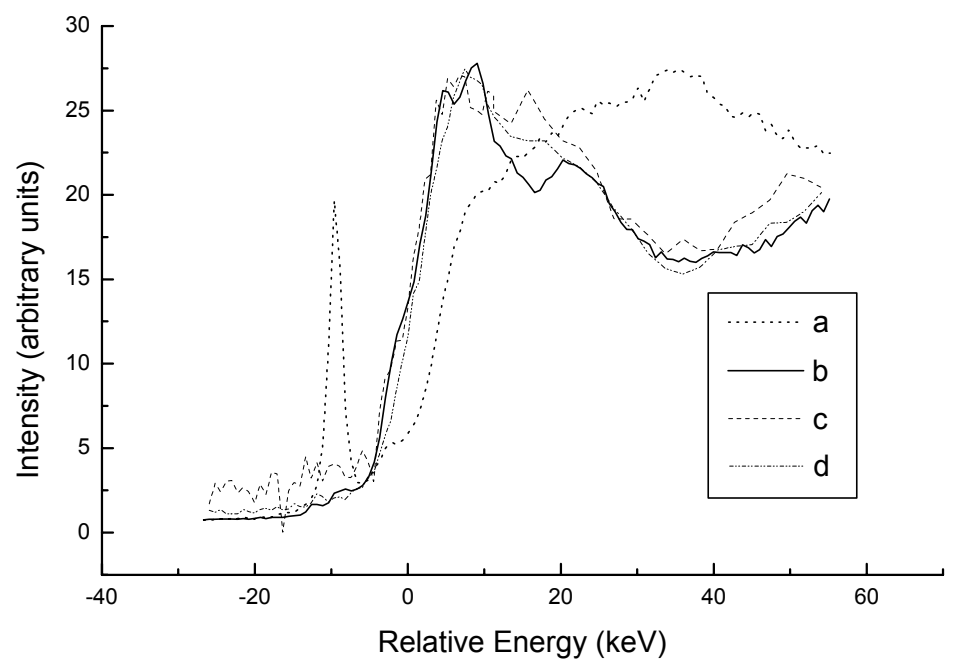

Figure 4. Micro-XANES spectra from the standards: (a) $\mathrm{Cr}(\mathrm{VI})$ and (b) $\mathrm{Cr}(\mathrm{III})$, and cells treated with (c) $\mathrm{Cr}(\mathrm{V})$ and (d) Cr(VI). Reprinted with permission from [9]. Copyright (1997) American Chemical Society.

Micro-SRIXE images of thin-sectioned cells (Figure 5) showed the intracellular Cr distribution following $\mathrm{Cr}(\mathrm{VI})$ exposure [6]. Cr was localised in two distinct regions. In one region $\mathrm{Cr}$ coexists with high concentrations of $\mathrm{Zn}$ (necessary for DNA transcription) and P (a component of the DNA backbone) suggesting that the $\mathrm{Cr}$ enters the nucleus. The second region of $\mathrm{Cr}$ may have resulted from the rapid reduction of $\mathrm{Cr}(\mathrm{VI})$ to $\mathrm{Cr}(\mathrm{III})$ and its consequent exclusion from the nucleus. The observation that $\mathrm{Cr}$ exists in localised sites, however, suggests encapsulation within a vacuole or some other organelle. 


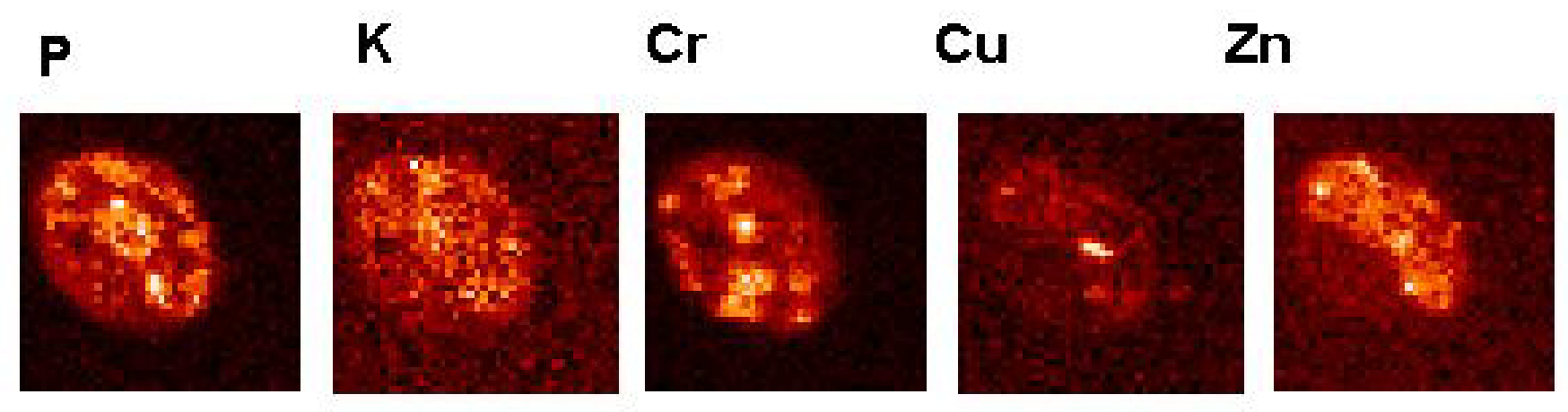

\section{Min}

\section{Max}

Figure 5. Micro-SRIXE elemental maps of V79 Chinese hamster lung cells that have been treated with Cr(VI). Map dimensions are $12 \times 12 \mu \mathrm{m}^{2}$, beam dimensions were $0.3 \mu \mathrm{m}^{2}$, step size was $0.3 \mu \mathrm{m}$. Adapted with permission from [6], Copyright [2002], Society of Biological Inorganic Chemistry.

\section{CONCLUSIONS}

Clearly, X-ray microscopy can provide crucial information to the understanding of specific biological problems, as shown in this study of $\mathrm{Cr}$ carcinogenesis. The ability of the technique to provide direct imaging of elements offers advantages over the imaging of radioactive- or fluorescent-labelled species as it avoids time-consuming, and sometimes hazardous synthetic preparations of the compounds. Similarly, X-ray microscopy avoids artefacts that may arise from altered cell metabolism due to the tagged drug. The ease of selecting scanning fluorescence and micro-XANES modes at the 2ID-D beam-line to within a micron represents a significant advancement towards robust and routine fluorescence and spectroscopic analysis, allowing the uptake of metal-based drugs to be chemically characterised on an intracellular level.

\section{Acknowledgments}

This work was supported by the Australian Research Council and the Australian Synchrotron Research Program, which is funded by the Commonwealth of Australia under the Major National Research Facilities Program. Use of the Advanced Photon Source was supported by the U.S. Department of Energy, Basic Energy Sciences, Office of Science, under Contract No. W-31-109-Eng-38. Sincerest thanks to Ms Jacqueline Isaacs (Dept Anatomy and Histology, University of Sydney) and Dr Clive Nockolds and Mr Tony Romeo (Electron Microscope Unit, University of Sydney).

\section{References}

[1] IARC (1990) IARC Monographs on the Evaluation of Carcinogenic Risk to Humans: Chromium, Nickel and Welding. Vol. 49. International Agency for Research on Cancer, Lyon, pp. 49-508.

[2] Codd R., Dillon C.T., Levina A. and Lay P.A., Coord. Chem. Rev. 216-217, (2001) 537-582.

[3] Levina A., Codd R., Dillon C.T. and Lay P.A., Prog. Inorg. Chem. (2002) Chromium in Biology: Toxicology and Nutritional Aspects. In Press.

[4] Inskeep R.G. and Bjerrum J., Acta Chem. Scand. 15, (1961) 62-68.

[5] Dillon C.T., Lay P.A., Bonin A.M., Dixon N.E. and Sulfab Y., Aust. J. Chem. 53 (2000) 411-424.

[6] Dillon C.T., Lay P.A., Kennedy B.J., Stampfl A.P.J., Cai Z., Ilinski P., Rodrigues W., Legnini D.G., Lai B. and Maser J., J. Biol. Inorg. Chem. 7 (2002) 640-645.

[7] GraphPad Software, Inc. (1995) GraphPad Prism,. (2.00 edn), San Diego, California.

[8] GraphPad Software, Inc. (1993) GraphPad Instat, San Diego, California.

[9] Dillon C.T., Lay P.A., Cholewa M., Legge G.J.F., Bonin A.M., Collins T.J., Kostka K.L. and SheaMcCarthy G., Chem. Res. Toxicol. 10 (1997) 533-535. 